\title{
Uptake of Some Toxic Elements by Wild Plants in Siwaqa Area/Central Jordan
}

\author{
Asma Fayyad Bzour*, Hani Nicola Khoury, Sawsan Attalah Oran ${ }^{1}$ \\ Department of Geology, University of Jordan, Amman 11942, Jordan \\ ${ }^{1}$ Department of Biological Sciences, University of Jordan, Amman 11942, Jordan
}

\section{*Correspondence to: \\ Bzour AF, \\ Fax: +962-795-482-658 \\ E-mail: asma.bzour.geo@gmail.com}

Received August 1, 2017

Revised September 14, 2017

Accepted September 17, 2017

\begin{abstract}
The wide distribution of redox-sensitive elements (RSE) as arsenic (As), cadmium (Cd), selenium (Se), and strontium (Sr) in the top soil of Siwaqa area are related to the weathering action of alkaline surface and groundwater on the parent rocks. The bioavailability, distribution, sorption, and ecotoxicity of $\mathrm{As}, \mathrm{Cd}, \mathrm{Se}$, and $\mathrm{Sr}$, of the wild plants and top soils in the study area were investigated. A total number of 23 surface soil samples and 23 plant samples were collected and analyzed for the most toxic elements. The uptake of elements by plants was dependent on the plant species and the concentration of elements in the soil. For example, Sr was the highest concentration in soil samples and plants, while Se was the lowest concentration in soil samples and pants. For the plants, the results showed that Bellevalia sp. had the highest elements uptake, while Allium rothii had the lowest elements uptake. The results of this work provide a valuable knowledge for understanding the bioavailability of some toxic elements in the soil and plants of Central Jordan. The results are expected to be of great help for the Jordanian Uranium Mining Company during their environmental risk assessments.
\end{abstract}

Key Words: Bioavailability, Central Jordan, Trace elements, Uptake, Transfer factor

\section{INTRODUCTION}

Heavy metals and trace elements such as: arsenic (As), cadmium (Cd), selenium (Se), and strontium (Sr) are naturally occurring in rocks and soil environment resulted from pedogenetic processes of weathering (Pierzynski et al., 2000). These elements are important in contaminating surface and ground waters and decreasing crop production as a result of bioaccumulation and biomagnification in the food chain. Knowledge of basic chemistry, environmental and associated health effects of these heavy metals is important to understand their speciation, bioavailability, and remedial options. Heavy metals are absorbed in the soil, by initial fast reactions (minutes, hours), followed by slow adsorption reactions (days, years) by plants, redistributed into different chemical forms with varying bioavailability, mobility, and toxicity (Shiowatana et al., 2001). Heavy metals distribution in soils take place as a result of mineral precipitation and dissolution, ion exchange, adsorption, aqueous complexation, biological immobilization and mobilization, and plant uptake (Levy et al., 1992). Potentially toxic elements in soils and plants may come from the bedrock itself and anthropogenic sources like solid or liquid waste deposits (Wilson \& Pyatt, 2007). Plants are important components of ecosystems as they transfer elements from abiotic into biotic environments. All plants have the ability to accumulate essential elements from the soil and need different concentrations from these elements for growth and development. This ability also allows plants to accumulate other non-essential elements which have not known biological function (Djingova \& Kuleff, 2000). Several studies have been carried out to evaluate and describe The accumulation of toxic trace elements and its impacts on the plant diversity were investigated by many authors and in different regions (Chen et al., 2005; Tomé et al., 2002). The soils and plants contain all naturally occuring radioactive elements with half-lives comparable to the age

(a) This is an open-access article distributed under the terms of the Creative Commons Attribution Non-Commercial License (http://creativecommons.org/licenses/by-nc/4.0) which permits unrestricted noncommercial use, distribution, and reproduction in any medium, provided the original work is properly cited.

Copyrights () 2017 by Korean Society of Microscopy 
of the earth, although their concentrations in plants may be rather low (Buck et al., 1996). The uptake of heavy metals by plant parts is real and not due to contamination by aerosols and was best illustrated by higest Ni uptake index in Atriplex leuceclada (Abed \& Al-Eisawi, 1994). Bzour et al. (2016) have investigated the potential mobilization and accumulation of $\mathrm{Cr}, \mathrm{V}$ and $\mathrm{U}$ in wild plants in Siwaqa area/Central Jordan and the results have indicated that the highest TF for $\mathrm{U}$ is $(0.25)$ and is recorded in Onopordum transjordanicum. Top soils of Central Jordan are enriched in redox sensitive trace elements such as $\mathrm{U}, \mathrm{Cr}, \mathrm{Zn}, \mathrm{Cr}, \mathrm{Ni}, \mathrm{Cu}, \mathrm{Co}$, As, and $\mathrm{Cd}$ in the form of sulphides and selenides (Fourcade et al., 2007; Khoury, 2012; Khoury et al., 2014, 2015; Khoury \& Nassir 1982; Nassir \& Khoury, 1982; Techer et al., 2006). The highest concentrations of trace elements from Central Jordan are present in the altered marble, chalk marl/travertine, and top soil (Elie et al., 2007; Khoury, 2015). Limited research was carried out on the the impact of trace elements on the wild plants in central Jordan. The impact dust and heavy metals emitted from petroleum refinery on plant diversity in Tafila/Jordan was investigated (Oran \& Abu Zahra, 2014; Oran \& Al-Zo'ubi, 2016). Recent work on central Jordan has indicated that redox sensitive elements are present in the structure of high and low temperature minerals and are adsorbed by the organic matter. of the parent bituminous rocks (Fourcade et al., 2007; Khoury et al., 2014, 2015, 2016; Techer et al., 2006). Heavy metals such as $\mathrm{U}, \mathrm{Cd}, \mathrm{As}, \mathrm{Cr}, \mathrm{Pb}, \mathrm{Ni}, \mathrm{Zn}$ and $\mathrm{V}$ are also enriched in the phosphate rocks of Central Jordan (Abed et al., 2008). The lack of knowledge of the behavior of some toxic trace elements in soils and plants in Central Jordan in addition to the planned mining activities by Jordan Uranium Minning Company (JUMCO) in the area have encouraged the authors to carry out this work., The transfer of As, Cd, Se and Sr, to the wild plants in terms of sorption, toxicity and speciation will be emphasized.

\section{Geology of Central Jordan}

The northern boundaries of the first and second areas of Central Jordan (Daba-Khan Al-Zabib-Siwaqa) are located 25 $\mathrm{km}$ and $60 \mathrm{~km}$ south of Amman with the first area situated between $\mathrm{E} 36^{\circ} 00^{\prime}$ to $36^{\circ} 15^{\prime}$ and $\mathrm{N} 31^{\circ} 15^{\prime}$ to $31^{\circ} 30^{\prime}$ and the second area between E $35^{\circ} 00^{\prime}$ to $36^{\circ} 15^{\prime}$ and $\mathrm{N} 31^{\circ} 15^{\prime}$ to $31^{\circ}$ 30'. Fig. 1A shows the location map of the studied area. The studied area was mapped in detail by the Natural Resources Authority (NRA) (Barjous, 1986; Jaser, 1986) and the geology, stratigraphy and sedimentology were described in details by Powell (1989) and Powell \& Moh'd (2011).

Fig. 1C is a generalized geological map of the study area (Barjous, 1986; Jaser, 1986; Khoury et al., 2014). Most of the outcropping rocks are of Upper Cretaceous age. The outcropping rocks of Central Jordan are sedimentary in origin and the exposed bed rock ranges in age from Turonian (Upper Cretaceous) to Eocene (Lower Tertiary). Outcrops in central Jordan illustrate the presence of three main rock types: Bituminous marl; varicolored marble (pyrometamorphic rocks); travertine and top soil. The Bituminous Marl Unit overlies the Phosphorite Unit and underlies the varicolored marble and all are of Maestrichtian-Lower Paleocene age (Barjous, 1986; Blake \& Ionides, 1939; Burdon, 1959; Jaser, 1986; Khoury et al., 2014; Quennel, 1956). In central Jordan, unusual redox-sensitive elements (RSE) cover large areas and are mainly associated with the varicolored marble, Pleistocene-Recent travertine and top soil. Yellow uranium encrustations and green $\mathrm{Cr}$-rich smectites are also associated
A

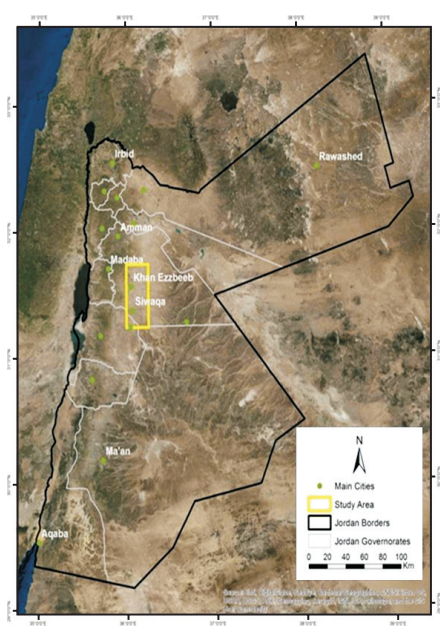

B

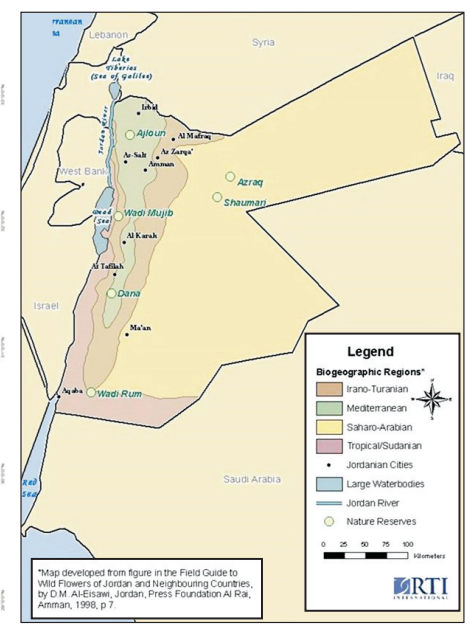

C

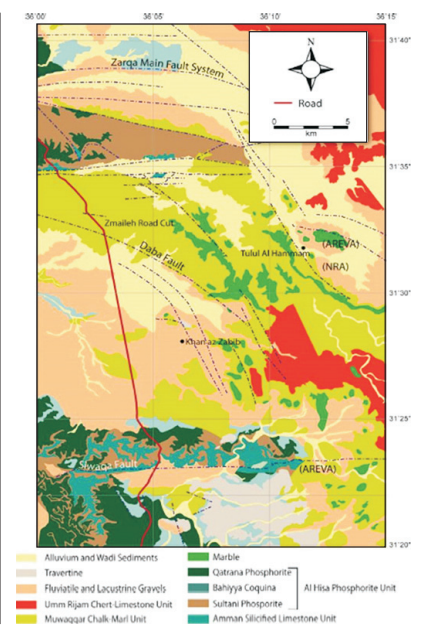

D

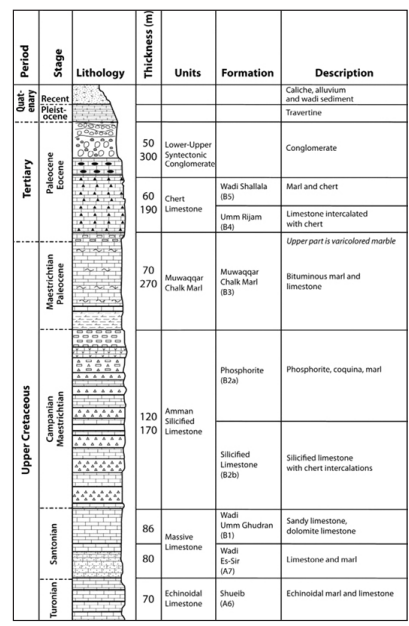

Fig. 1. (A) Location map of Jordan showing the study area. (B) Location map of the study area showing the vegetation regions (after Al-Eisawi, 1996). (C) Geological map of central Jordan (modified after Barjous, 1986; Jaser, 1986; Khoury et al., 2014). (D) Simplified geologic section of central Jordan. 
with the varicolored marble (pyrometamorphic rocks) and the underlying bituminous marl (oil shale) and phosphorites 9 (Khoury, 2006; Khoury \& Abu-Jayyab, 1995; Khoury et al., 1984, 2014). The mineralogy of surficial top soil in central Jordan and RSE source rocks, transport conditions, and deposition processes were explained in detail by Khoury et al. (2014). The geochemistry of uranium and vanadium of the mineral phases was not investigated in detail. The general chronological sequence of the different lithological units is illustrated in Fig. 1D. The Upper Cretaceous to Tertiary rocks in Central Jordan were deposited at the margin of the Tethys shelf-sea in environments ranging from super-tidal to deep sub-tidal (Bender, 1968). Transgression took place during Cenomanian times and marine sedimentation continued until the Late Eocene, despite fluctuations in sea level. Gentle folding, block faulting and possible strike- slip faulting were related to continued tectonic movement on the Jordan Rift structure which is located $60 \mathrm{Km}$ to the west of the study area
(Bender, 1968; Powell, 1989; Powell \& Moh'd, 2011).

\section{Bioclimatic and Vegetation Regions of Central Jordan}

Central Jordan is classified as arid Mediterranean bioclimate; cool, warm and very warm varieties (Al-Eisawi, 1996). The largest area of Central Jordan is located in arid Mediterranean warm variety bioclimatic zone and located in Irano-Turanian vegetation region, while the north west of Central Jordan is in Mediterranean vegetation region and a very small part of south east of central Jordan located in Saharo-Arabian vegetation regions Fig. 1B. The vegetation is mostly herbs, shrubs and bushes with no trees (Al-Eisawi, 1996).

\section{MATERIALS AND METHODS}

\section{Field and Laboratory Work}

Field trips were conducted extensively to Siwaqa area, Central desert of Jordan. Fresh plant specimens and soil samples
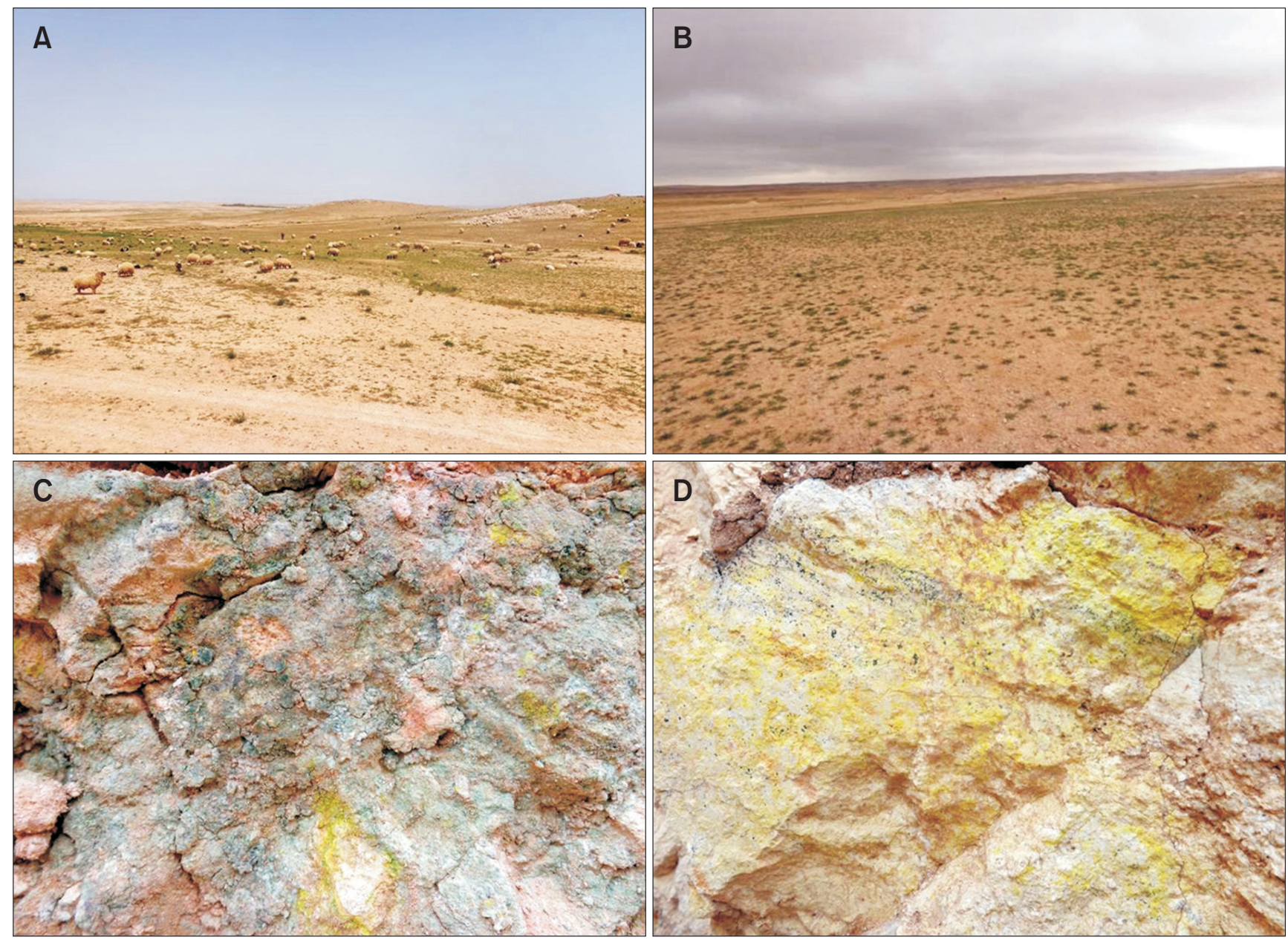

Fig. 2. (A) Landscape of the study area showing grazing by herbavious animals. (B) A Photograph showing a general view of the landscape indicating the scarcity of vegetation cover. (C) A photograph illustrates the presence of secondary encrustations of uranium and Cr-rich smectites in the altered marble/ top soil. (D) A phtograph of yellow secondary uranium minerals filling porous rocks. 
were collected for every plant species available at the time of sampling and were placed in plastic bags. Global positioning system (GPS) records were made from the sampling sites during the period of the study. Sample locations were chosen randomly referring to the availability of plant species and sampling was based on ease of access, adequate vegetation growth to provide vegetation samples. Plant specimens were identified based on: Flora Palaestina (parts 1, 2, 3, and 4) (Feinbrun, 1986; Zohary, 1966). Field Guide to Wild Flowers of Jordan and Neighboring Countries (Al-Eisawi, 1998). Siwaqa area is dry with scare vegetation; wild plants and green grass cover the landscape during Spring time that is used by locals for grazing and as folk medicine (Fig. 2A). A number of 23 soil samples and 23 plant samples were collected. Fig. $2 \mathrm{~B}$ shows a general view of the landscape in Siwaqa area indicating the scarcity of vegetation cover. The top soil is porous and is mainly composed of calcite and gypsum. Secondary green Cr-rich smectite and yellow uranium minerals are common features filling voids and planes of weakness. Yellow secondary uranium minerals (source of
$\mathrm{U}$ and V) together with green $\mathrm{Cr}$ - rich smectites are almost always associated together in the top soil and the underlying travertine and altered marble (Fig. $2 \mathrm{C}$ and D). Fig. 3 are selected photographs of some typical wild plants from Siwaqa area.

Plant samples were carefully brush-washed with tab water and again washed and rinsed with distilled water to remove externally adhered metals and dust from the surface of the plants. The plants were oven dried at $100^{\circ} \mathrm{C}$ overnight. The samples were ground in a small coffee grinder. Finally, the samples were ground into fine powder by using Mill mix.

Soil samples were oven dried at $100^{\circ} \mathrm{C}$ overnight, then sieved through 63 microns mesh screen into fine powder. The samples were characterized using chemical methods. All the analytical work was carried out in the laboratories of the Department of Geology, University of Jordan and the Jordan Atomic Energy Commission (JAEC).

Inductively coupled plasma mass spectrometry (ICP-MS) analyses were carried out in the Chemical Analysis Section, chemical and physical analysis laboratories, Nuclear Fuel
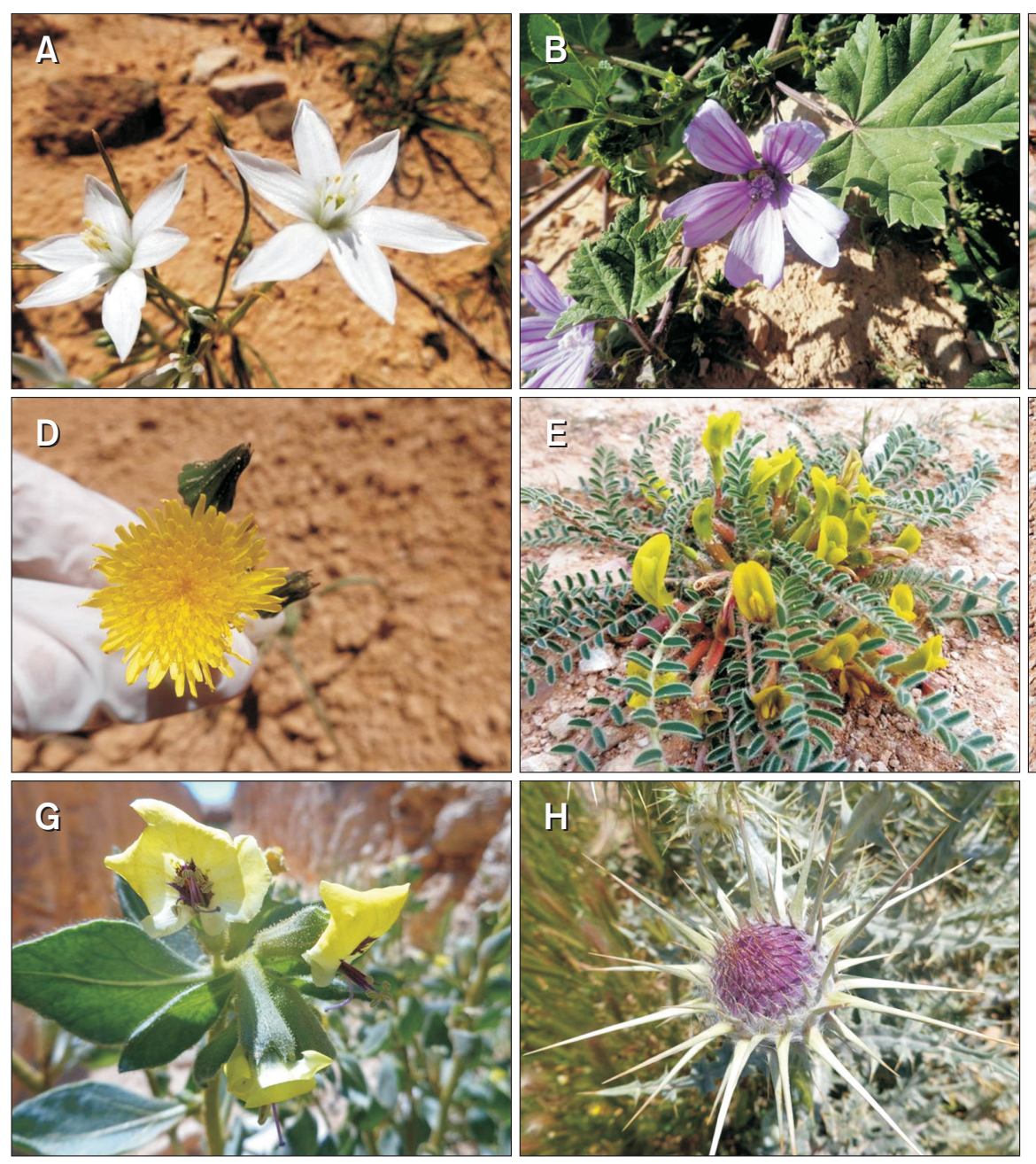
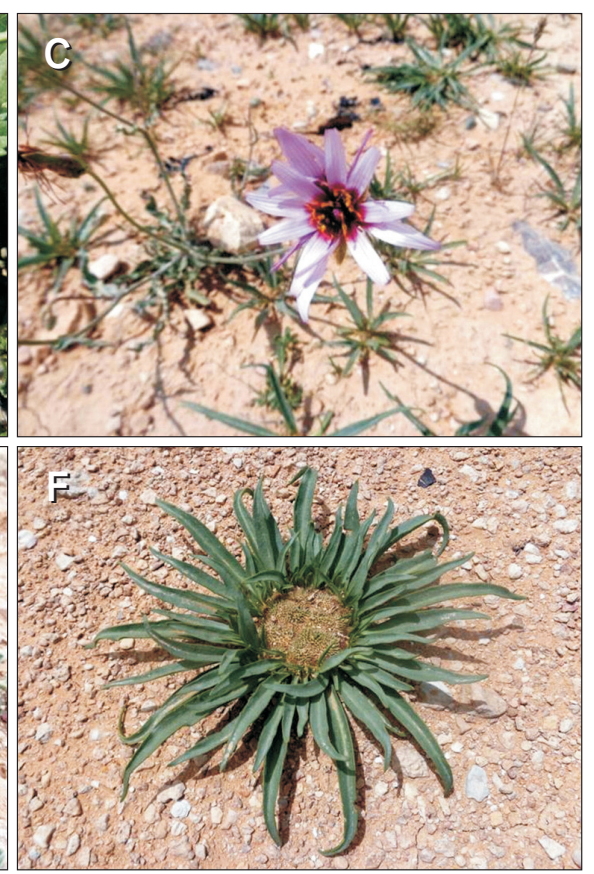

Fig. 3. Photographs of wild plants. (A) Ornithogalum trichophyllum, (B) Malva sylvestris, (C) Scorzonera papposa, (D) Senecio flavus, (E) Astragalus sparsus, (F) Gymnarrhena micranta, (G) Hyoscyamus desertorum, $(\mathrm{H})$ Onopordum transjordanicum. 
Cycle Commission (NCC-CPAL), JAEC. The ICP-MS (ELAN ${ }^{\circledR}$ DRC-e; PerkinElmer SCIEX, Canada) was used to measure the amount of toxic trace elements in plants and soil particles. All samples were sent via JUMCO to ALS Arabia Co. Ltd. Jeddah, Saudi Arabia to be analyzed.

The TF was used as an index for the accumulation of trace elements by plants or the transfer of elements from soil to plants in mg. $\mathrm{Kg}^{-1}$ (Whicker et al., 1999; Yanagisawa et al., 1992). The transfer factor TF is defined as a factor used to describe the amount of element which is expected to be transferred to plant from soil. It is also defined as the ratio of specific activities in plant parts and soil (in $\mathrm{Bq} \mathrm{kg}{ }^{-1}$ dry weight plant part divided by Bq kgl dry weight soil).

\section{RESULTS AND DISCUSSION}

\section{Mass Spectrometry Analysis (ICP-MS)}

The mass spectrometry analysis (ICP-MS) results are given in Table 1. Table 1 includes the concentration results of As, Cd,
Se and Sr, in the soil and plant samples and their calculated TFs.

\section{Arsenic (As)}

As is a carcinogen, and associated with human skin, lung and bladder cancers (ATSDR, 2005; Ng et al., 2003). The permissible limit of As in soil which recommended by World Health Organization (WHO, 2007) and Pendias \& Pendias (2000) is $10 \mathrm{mg} / \mathrm{kg}$ As. The toxic limit of As in plant species is 0.1 recommended by WHO (2007). The concentrations of (As) in the soils of Siwaqa area ranged between 4.7 to $14.8 \mathrm{mg} / \mathrm{kg}$ with a mean value of $8.4 \mathrm{mg} / \mathrm{kg}$. The highest value of (As) in the plant species of the study area is 2.11 $\mathrm{mg} / \mathrm{kg}$ and is recorded in Bellevalia sp. The lowest value of (As) concentration is $0.13 \mathrm{mg} / \mathrm{kg}$ and is recorded in Allium rothii. The mean value is $0.99 \mathrm{mg} / \mathrm{kg}$. Fig. 4 illustrates the (As) concentrations in the plant species of the study area. The mean transfer factor from soil to plant of Siwaqa area is 0.12 . The highest transfer factor is 0.25 in Onopordum

Table 1. Trace elements concentrations (mg/Kg) in soil, plant and their TFs of Siwaqa area

\begin{tabular}{|c|c|c|c|c|c|c|c|c|c|c|c|c|c|}
\hline \multirow{2}{*}{$\begin{array}{l}\text { Location } 1 \\
\text { Sample ID }\end{array}$} & \multicolumn{4}{|c|}{ Soils } & \multirow{2}{*}{ Plant name } & \multicolumn{4}{|c|}{ Plants } & \multicolumn{4}{|c|}{ TFs } \\
\hline & As & $\mathrm{Cd}$ & $\mathrm{Se}$ & $\mathrm{Sr}$ & & As & $\mathrm{Cd}$ & Se & $\mathrm{Sr}$ & As & $\mathrm{Cd}$ & Se & $\mathrm{Sr}$ \\
\hline 1 & 6.28 & 2.49 & 1.5 & 380 & Bassia eriophora & 1.02 & 1.2 & 0.31 & 163 & 0.2 & 0.5 & 0.2 & 0.43 \\
\hline 2 & 7.79 & 4.98 & 2 & 511 & Arthocnemum mucronatum & 0.36 & 1.7 & 0.16 & 290 & 0.05 & 0.3 & 0.08 & 0.57 \\
\hline 3 & 7.61 & 5.23 & 2.5 & 536 & Astragalus spinosus & 0.98 & 0.5 & 0.43 & 234 & 0.1 & 0.1 & 0.17 & 0.44 \\
\hline 4 & 7.51 & 3.68 & 1.8 & 447 & Onopordum transjordanicum & 1.9 & 1.4 & 0.4 & 480 & 0.25 & 0.36 & 0.22 & 1.07 \\
\hline 5 & 9.8 & 5.08 & 2.2 & 567 & Bellevalia sp. & 2.11 & 5.11 & 4.34 & 276 & 0.2 & 1.006 & 1.97 & 0.5 \\
\hline 6 & 9.92 & 4.97 & 2.5 & 582 & Astragalus sp. & 0.81 & 0.46 & 0.3 & 240 & 0.08 & 0.025 & 0.11 & 0.4 \\
\hline 7 & 9.56 & 3.9 & 1.9 & 556 & Matthiola sp. & 0.72 & 0.46 & 0.31 & 741 & 0.075 & 0.1 & 0.16 & 1.33 \\
\hline 8 & 4.93 & 5.78 & 1 & 318 & Allium rothii & 0.13 & 0.13 & 0.11 & 99.5 & 0.026 & 0.01 & 0.107 & 0.3 \\
\hline 9 & 4.7 & 3.23 & 1.3 & 403 & Scorzonera schweinfurthii & 0.37 & 0.37 & 0.14 & 202 & 0.08 & 2 & 0.11 & 0.5 \\
\hline 10 & 8.2 & 2.97 & 1.9 & 498 & Senecio flavus & 1.49 & 1.1 & 0.27 & 300 & 0.2 & 0.37 & 0.145 & 0.6 \\
\hline 11 & 10.1 & 3.56 & 2.1 & 493 & Peganum harmala & 0.86 & 1.08 & 0.34 & 292 & 0.1 & 0.3 & 0.16 & 0.6 \\
\hline 12 & 7.48 & 5.68 & 1.9 & 480 & Onopordum transjordanicum & 1.31 & 1.08 & 0.32 & 453 & 0.2 & 0.2 & 0.17 & 0.94 \\
\hline 14 & 14.8 & 10.1 & 6.1 & 781 & Hordeum glaucus & 1.19 & 0.77 & 0.27 & 119 & 0.08 & 0.076 & 0.044 & 0.15 \\
\hline 26 & 10.15 & 9.09 & 2.8 & 439 & Malva sylvestris & 1.39 & 1.73 & 0.28 & 270 & 0.1 & 0.2 & 0.1 & 0.6 \\
\hline 27 & 9.55 & 6.1 & 2.1 & 415 & Hordeum glaucus & 0.69 & 0.3 & 0.12 & 87.4 & 0.07 & 0.05 & 0.056 & 0.2 \\
\hline 28 & 10.55 & 9.67 & 2.3 & 478 & Onopordum transjordanicum & 1.55 & 1.8 & 0.24 & 247 & 0.1 & 0.2 & 0.1 & 0.5 \\
\hline 29 & 10.8 & 9.39 & 2.2 & 544 & Hyoscyamus desertorum & 1.28 & 0.96 & 0.18 & 153.5 & 0.1 & 0.1 & 0.08 & 0.3 \\
\hline 31 & 10.6 & 10.25 & 2.7 & 450 & Reichardia tingitana & 1.01 & 2.84 & 0.14 & 229 & 0.1 & 0.3 & 0.05 & 0.5 \\
\hline 32 & 5.39 & 7.56 & 1.6 & 387 & Matthiola sp. & 0.36 & 0.74 & 0.14 & 699 & 0.07 & 0.1 & 0.09 & 1.8 \\
\hline 33 & 5.21 & 5.89 & 1.6 & 400 & Allium rothii & 0.93 & 1.52 & 0.28 & 229 & 0.2 & 0.25 & 0.17 & 0.57 \\
\hline 34 & 6.66 & 9.14 & 2.1 & 450 & Gymnarrhena micrantha & 1.05 & 1.5 & 0.22 & 162.5 & 0.15 & 0.16 & 0.1 & 0.36 \\
\hline 35 & 7.21 & 11.85 & 2.1 & 438 & Maresia pygmaea & 0.62 & 2.12 & 0.23 & 381 & 0.1 & 0.16 & 0.11 & 0.9 \\
\hline 36 & 7.6 & 8.72 & 2.2 & 451 & Gynandriris sisyrinchium & 0.68 & 1.3 & 0.12 & 177 & 0.1 & 0.15 & 0.1 & 0.4 \\
\hline Mean & 8.4 & 6.5 & 2.2 & 478 & & 0.99 & 1.31 & 0.42 & 283.7 & 0.12 & 0.23 & 0.2 & 0.607 \\
\hline STADEV & 2.4 & 2.8 & 0.95 & 93.3 & & 0.5 & 1.1 & 0.86 & 169.8 & 0.06 & 0.2 & 0.4 & 0.4 \\
\hline SEM & 0.5 & 0.6 & 0.199 & 19.5 & & 0.1 & 0.2 & 0.18 & 35.41 & 0.01 & 0.04 & 0.8 & 0.08 \\
\hline Minimum & 4.7 & 2.49 & 1 & 318 & & 0.13 & 0.13 & 0.11 & 87.4 & 0.026 & 0.025 & 0.044 & 0.15 \\
\hline Median & 7.79 & 5.78 & 2.1 & 451 & & 0.98 & 1.1 & 0.27 & 240 & 0.1 & 0.16 & 0.11 & 0.5 \\
\hline Maximum & 14.8 & 11.85 & 6.1 & 781 & & 2.11 & 5.11 & 4.34 & 741 & 0.25 & 1.006 & 1.97 & 1.8 \\
\hline Number of values & 23 & & & & & & & & & & & & \\
\hline
\end{tabular}

As, arsenic; Cd, cadmium; Se, selenium; Sr, strontium; SEM, standard error of the mean. 
transjordanicum. The lowest TF is 0.026 in Allium rothii.

\section{Cadmium (Cd)}

$\mathrm{Cd}$ is an extremely toxic metal which has no known necessary function in the body. Cadmium toxicity contributes to a large number of health conditions, including the major killer diseases such as heart disease, cancer and diabetes (Sheppard \& Sheppard, 1985). The permissible limit of $\mathrm{Cd}$ in soil as recommended by WHO (2007) is $5 \mathrm{mg} / \mathrm{kg}$. The toxic limit of Cd to the plant species recommended by WHO (2007) is $0.02 \mathrm{mg} / \mathrm{kg}$. The concentrations of Cd in soils of Siwaqa area ranged between 2.49 to $11.85 \mathrm{mg} / \mathrm{kg}$ with mean $6.5 \mathrm{mg} / \mathrm{kg}$. Some of collected soil samples from this area are above the permissible limit. The highest value of Cd content is $5.11 \mathrm{mg} /$

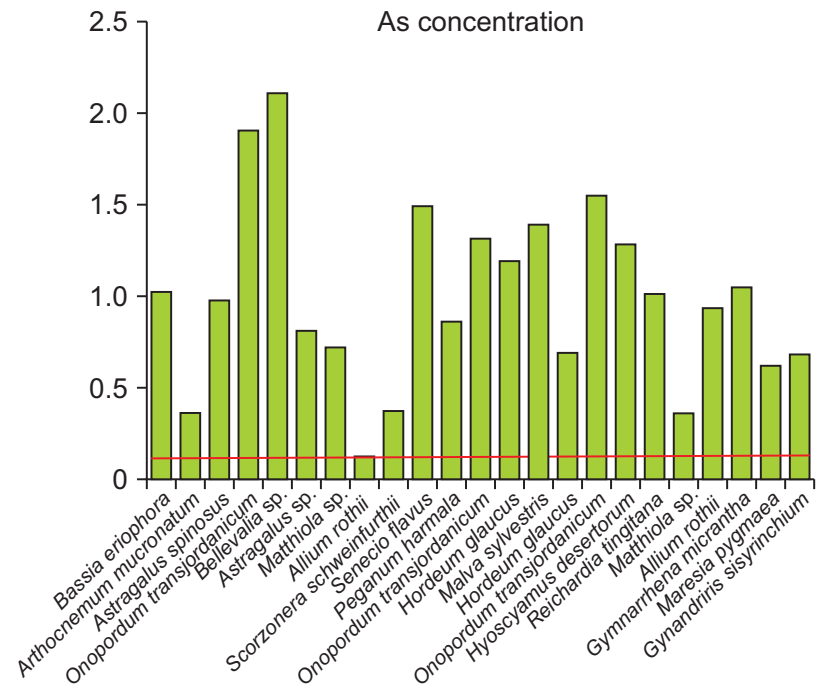

Fig. 4. Arsenic (As) concentrations in wild plant sp. in Siwaqa area.

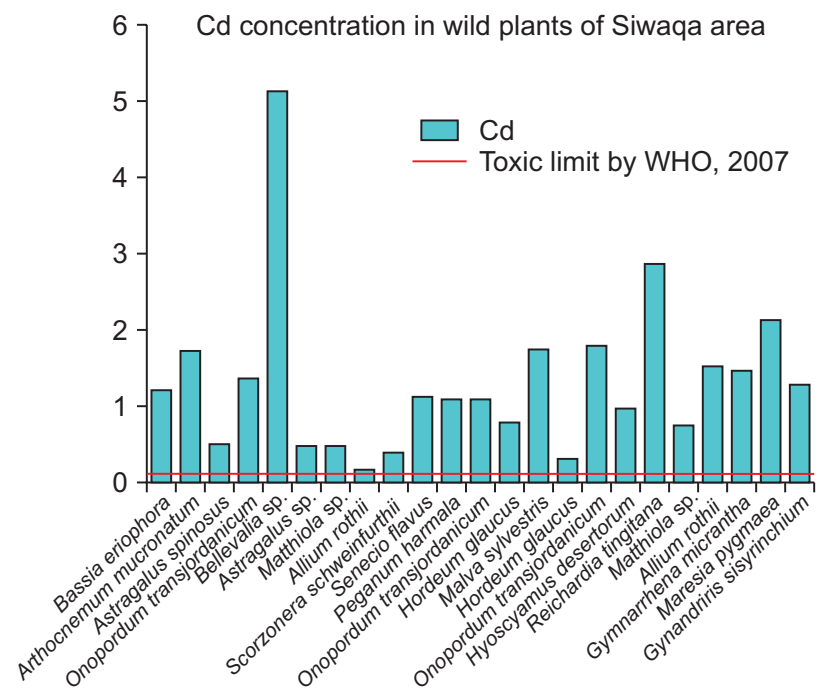

Fig. 5. Cadmium (Cd) concentrations in wild plant sp. in Siwaqa area. $\mathrm{kg}$ in plant species of Siwaqa area and is recorded in Bellevalia sp. The lowest value of Cd concentration is $0.13 \mathrm{mg} / \mathrm{kg}$ and is recorded in Allium rothii. The mean value is $1.31 \mathrm{mg} / \mathrm{kg}$. According to WHO (2007), all plant species of Siwaqa area are above the toxic limits. Fig. 5 shows the Cd concentrations in the wild plant species of the study area. The mean transfer factor of Cd from soil to plant of Siwaqa area is 0.23 . The highest transfer factor is 1.006 in Bellevalia sp. The lowest TF is 0.025 in Astragallus sp.

\section{Selenium (Se)}

The average content of selenium in the Earth's crust is estimated as $0.05 \mathrm{mg} / \mathrm{kg}$ (Pendias \& Pendias, 2000). Toxic Se concentration limit is $0.5 \mathrm{mg} / \mathrm{kg}$ soils (Pendias \& Pendias, 2000) and 0.05 in plants according to WHO (2007). The concentrations of Se in soils of Siwaqa area range between 1 to $6.1 \mathrm{mg} / \mathrm{kg}$ with a mean value of $2.2 \mathrm{mg} / \mathrm{kg}$. All soil samples of Siwaqa area are above the permissible limit for Se as recommended by Pendias \& Pendias (2000). The highest value of Se content in plant species of Siwaqa area is $4.34 \mathrm{mg} / \mathrm{kg}$ and is recorded in Bellevalia sp. The lowest value of Se content is $0.11 \mathrm{mg} / \mathrm{kg}$ and is recorded in Allium rothii, the mean value is $0.42 \mathrm{mg} / \mathrm{kg}$. Fig. 6 indicates that all plant species recorded in the study area have exceeded the toxic limit as recommended by the WHO. The mean value of transfer factor of Se from soil to plant of the study area is 0.2 . The highest transfer factor is 1.97 and is found in Allium rothii. The lowest TF value is 0.044 and is found in Hordeum glaucus.

\section{Strontium (Sr)}

$\mathrm{Sr}$ is a relatively common element in the Earth's crust and its contents range between 260 and $370 \mathrm{mg} / \mathrm{kg}$ (Pendias \& Pendias, 2000). According to Pendias \& Pendias (2000), 150

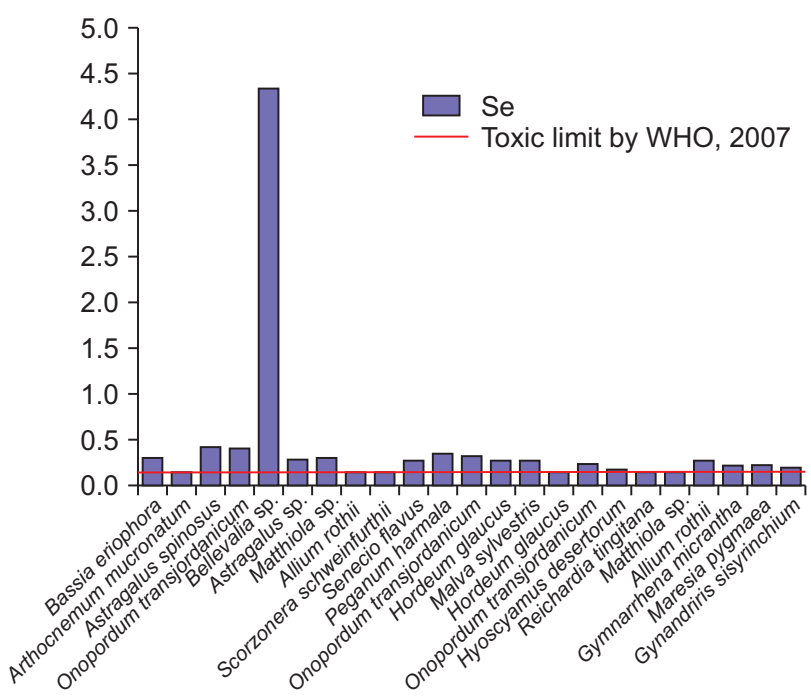

Fig. 6. Selenium (Se) concentrations in wild plant species of Siwaqa area. 


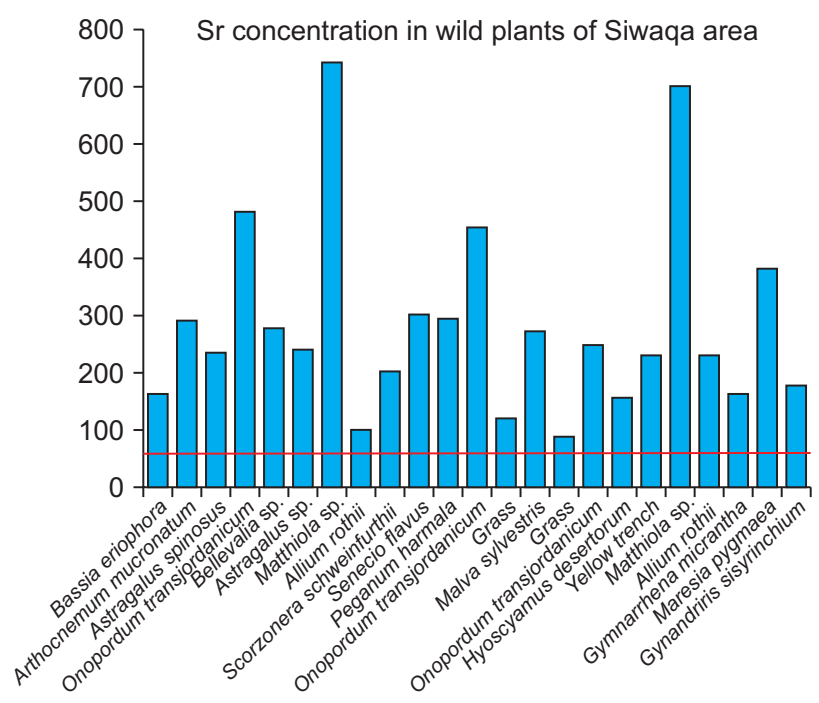

Fig. 7. Strontium (Sr) concentrations in wild plant species of Siwaqa area.

$\mathrm{mg} / \mathrm{kg}$ concentration value of $\mathrm{Sr}$ in soils is toxic, and $50 \mathrm{mg} /$ $\mathrm{kg}$ concentration value of $\mathrm{Sr}$ in plants is highly toxic referring to WHO (2007). The concentrations of $\mathrm{Sr}$ in the soils of Siwaqa area range between 318 to $781 \mathrm{mg} / \mathrm{kg}$ with a mean value of $478 \mathrm{mg} / \mathrm{kg}$. All soil samples in this area are above the toxic limit as recommended by Pendias \& Pendias (2000). The highest value of Sr content in plant species of Siwaqa area is $741 \mathrm{mg} / \mathrm{kg}$ and is recorded in Mathiola sp. The lowest value of Sr content is $87.4 \mathrm{mg} / \mathrm{kg}$ and is recorded in Hordeum glaucus. The mean value is $283.7 \mathrm{mg} / \mathrm{kg}$. The $\mathrm{Sr}$ toxic limit as recommended by WHO (2007) is below the all concentrations of $\mathrm{Sr}$ in all plant species collected from this area. Fig. 7 shows the $\mathrm{Sr}$ concentrations in plant species of the study area. The mean transfer factor from soil to plant of the study area is 0.607. The highest transfer factor is 1.8 in Mathiola sp., and the lowest TF is 0.15 in Hordeum glaucus.

\section{CONCLUSIONS}

The present work is aimed to characterize the soil and the ability of wild plant species in Siwaqa area/Central Jordan to absorb different hazardous trace elements chemically and mineralogically. The behavior of toxic heavy metals and trace elements (As, Cd, Se, and $\mathrm{Sr}$ ) in soils and plants was investigated. The ability to assess of wild plant species in Siwaqa area/ Central Jordan for the absorption of different hazardous trace elements. The environmental geochemical survey has revealed variations of trace elements concentrations in soils and plant species. The sources of trace elements are related to the leaching processes from the parent rocks of the area. The potential mobilization of As, Cd, Se and $\mathrm{Sr}$, seems to decrease as follows: $\mathrm{Sr}>\mathrm{As}>\mathrm{Cd}>\mathrm{Se}$. The absorption of these elements in plants is variable from one species to another, but the majority of plants shows that the accumulation of metals followed this order: $\mathrm{Sr}>\mathrm{Cd}>\mathrm{As}>\mathrm{Se}$, indicating that the metal release in the soils correlates with their absorption by the plants. The concentration of these elements was depend on climatic geologic events in Central Jordan. Differences between trace elements TFs values for various plant species are related to the different characteristics and behavior of the wild plants. In general, the comparative uptake of trace elements is affected by numerous physical, chemical and biological conditions of the soil. The uptake of elements by plants depends on the plant species and the concentration of elements in the soil. The values are above the permissible limits according to WHO. The information on the concentration level and transfer of (As, Cd, Se, and $\mathrm{Sr}$ ) from soil to plant will provide important information during the environment risk assessment that is expected to be carried out by JUMCO in the near future. Further studies and investigations are needed to assess and evaluate the ecotoxicity of heavy metals on plant species by the different RSE in the different soils of Central Jordan.

\section{CONFLICT OF INTEREST}

No potential conflict of interest relevant to this article was reported.

\section{ACKNOWLEDGMENTS}

The financial help of the Deanship of Academic Research, University of Jordan and the Jordanian Uranium Mining Company (JUMCO) is highly appreciated. Special thanks are given to Dr. Samer Kahook and Dr. Hussein Allaboun from JUMCO for their support during the progress of this work.

\section{REFERENCES}

Abed A and Al-Eisawi D (1994) The geobotanical exploration for Copper and Manganese in north-eastern Wadi Araba, Jordan. Dirasat. 21 189-201.

Abed A, Sadaqah R, and Al Kuisi M (2008) Uranium and potentially toxic metals during the mining, beneficiation, and processing of phosphorite and their effects on ground water in Jordan. Mine Water Environ. 27, 171-182.

Agency for Toxic Substances and Disease Registry (2005) Toxicological 
profile for Arsenic (Draft for public comment) (U. S. Department of Public Health and Human Services, Public Health Service, Atlanta).

Al-Eisawi D M (1996) Vegetation of Jordan. p. 284, (UNESCO (ROSTAS), Cairo Office, Cairo).

Al-Eisawi D M (1998) The field guide to wild flowers of Jordan and neighboring countries. Press Foundation Al-Rai. pp. 296.

Barjous M (1986) The Geology of Siwaqa. Bull. 4, NRA, Amman-Jordan.

Bender F (1968) Geologie von Jordanian. Beitrage zur Regionalen Geologie der Erde, Band 7. Borntraeger, Berlin.

Blake G and lonides M (1939) Report on the Water Resources of Transjodan and their Development (Crown Agents for Colonies, London).

Buck E C, Brown N R, and Dietz N L (1996) Contaminant uranium phases and leaching at the Fernald site in Ohio. Environ. Sci. Technol. 30, 81-88.

Burdon D (1959) Handbook of the Geology of Jordan (Benham and Company Ltd., Colchester).

Bzour A F, Khoury H N, and Oran S A (2016) Assessment of bioavailability of chromium (Cr), vanadium (V) and uranium $(\mathrm{U})$ in wild plants in Siwaqa area, Central Jordan. International Journal of Current Research of Biosciences and Plant Biology. 3, 84-94.

Chen S B, Zhu Y G, and Hu Q H (2005) Soil to plant transfer of ${ }^{238} \mathrm{U},{ }^{226} \mathrm{Ra}$ and ${ }^{232} \mathrm{Th}$ on a uranium mining-impacted soil from southeastern China. J. Environ. Radioactivity. 82, 223-236.

Djingova R and Kuleff I (2000) Instrumental techniques for trace analysis. In: Trace Elements: Their Distribution and Effects in the Environment. Vernet J P, ed. p. 146. (Elsevier science Ltd., United Kingdom),

Elie M, Techer I, Trotignon L, Khoury H, Salameh E, Vandamme D, Boulvais P, and Fourcade S (2007) Cementation of kerogen-rich marls by alkaline fluids released during weathering of thermally metamorphosed marly sediments. Part II: Organic matter evolution, magnetic susceptibility and metals $(\mathrm{Ti}, \mathrm{Cr}, \mathrm{Fe})$ at the Khushaym Matruck natural analogue (central Jordan). Applied Geochemistry. 22, 1311-1328.

Feinbrun N (1986) Flora Palaestina. Vol. III, IV. (The Israel Academy of Sciences and Humanities, Jerusalem).

Fourcade S, Trotignon, L, Boulvais P, Techer I, Elie M, Vandamme D, Salameh E, and Khoury H (2007) Cementation of kerogen-rich marls by alkaline fluids released during weathering of thermally metamorphosed marly sediments. Part I: Isotopic (C, O) study of the Khushaym Matruk natural analogue (central Jordan). Applied Geochemistry 22, 1293-1310.

Jaser D (1986) The geology of Khan Ez Zabib, Bull. Amman, Jordan, NRA, $3 p$.

Khoury H (2006) Industrial rocks and minerals in Jordan, second edition, Publications of the University of Jordan.

Khoury H (2014) Geochemistry of surficial uranium deposits from central Jordan. Jordan Journal of Earth and Environmental Sciences (JJEES) 3, 11-22.

Khoury H, Kokh S, Sokol E, Likhacheva A, Seryotkin Y, and Belogub E (2016) Ba- and Sr-mineralization of fossil fish bones from metamorphosed Belqa Group sediments, central Jordan, Arabian Journal of Geosciences 9, 461.

Khoury H, Mackenzie R, Russell J, and Tait J (1984) An iron-free volkonskoite. Clay Minerals. 19, 43-57.

Khoury H, Salameh E, and Clark I (2014) Mineralogy and origin of surficial uranium deposits hosted in travertine and calcrete from central
Jordan. Applied Geochemistry 43, 49- 65.

Khoury H, Sokol E, and Clark I (2015) Calcium uranium oxides from central Jordan: associations, chemistry, and alteration products. Canadian Mineralogist. 53, 61-82.

Khoury $\mathrm{H}$ and Nassir S (1982) A discussion on the origin of Daba-Siwaqa marble, Dirasat. 9, 55-56.

Khoury H N (2012) Long-term analogue of carbonation in Travertine from Uleimat Quarries, Central Jordan. Environ Earth Sci. 65, 1906-1916.

Khoury H N (2015) Uranium minerals of Central Jordan. Applied Earth Science (Trans. Inst. Min. Metall. B) 124, 104-128.

Khoury H N and Abu-Jayyab A (1995) A short note on the mineral volkonskoite, Dirasat. 1, 189-198.

Levy D B, Barbarick K A, Siemer E G, and Sommers L E (1992) Distribution and partitioning of trace metals in contaminated soils near Leadville, Colorado. J. Environ. Qual. 21, 185-195.

Nassir S and Khoury H N (1982) Geology, mineralogy and petrology of Daba marble, Jordan. Dirasat. 9, 107-140.

Oran S A and Abu Zahra H (2014) Impact of the cement dust emitted from the south cement factory in Tafila/Jordan on plant diversity of the surrounding area. Int J Biodivers Conserv. 6, 400-414.

Oran S A and Al-Zo'ubi E (2016) The impact of the emitted dust from Zarka (Jordan) petroleum refinery on plant biodiversity. Int. J. Curr. Res. Biosci. Plant Biol. 3, 1-13.

Pendias A K and Pendias H (2000) Trace elements in Soils and Plants. 3. FL, United States: CRC press. pp. 10-11.

Pierzynski G M, Sims J T, and Vance G F (2000) Soils and Environmental Quality, CRC Press, London, UK, 2nd edition.

Powell J H (1989) Stratigraphy and Sedimentology of the Phanerozoic Rocks in Central and Southern Jordan. Bull. 11, Geology Directorate, Natural Resources Authority (Ministry of Energy and Mineral resources) Amman, Part B: Kurnub, Ajlun and Belqa Group, 161P.

Powell J H and Moh'd B K (2011) Evolution of Cretaceous to Eocene alluvial and carbonate platform sequences in central and south Jordan. GeoArabia. 16, 29-82.

Quennel A (1956) The structural and geomorphic evaluation of the Dead Sea Rift. Quart. J. Geol. Sci. Lond. 64, 1-24.

Sheppard M I and Sheppard S C (1985) The plant concentration ratio concept as applied to natural U. Health Phys. 48, 494-500.

Shiowatana J, McLaren R, Chanmekha N, and Samphao A (2001) Fractionation of arsenic in soil by a continuous-flow sequential extraction method. J. Environ. Qual. 30, 1940-1949.

Techer I, Khoury H, Salameh E, Rassineux F, Claude C, Clauer N, Pagel M, Lancelot J, Hamelin B, and Jacquot E (2006) Propagation of high-alkaline fluids in an argillaceous formation: case study of the Khushaym Matruk natural analogue (Central Jordan). Jour. Of Geoch. Exploration. 90, 53-67.

Tomé V, Rodrigues P, and Lozano J (2002) Distribution and mobilization of $\mathrm{U}$, Th and ${ }^{226} \mathrm{Ra}$ in the plant-soil compartments of a mineralized uranium area in South-West Spain. J. Environ. Radioactivity 59, 223243.

Whicker F W, Hinton T G, Orlandini K A, and Clark S B (1999) Uptake of natural and anthropogenic actinides in vegetable crops grown on a contaminated lake bed. J. Environ. Radioactivity 45, 1-12.

Wilson B and Pyatt B (2007) Heavy metal dispersion, persistence and bioaccumulation around an ancient copper mine situated Anglesey, UK. Ecotoxicol Environ Saf. 66, 224-231. 
World Health Organization (2007) Joint FAO/WHO Expert standards program codex Alimentation Commission. Geneva, Switzerland [Internet]. Available from: http://www.who.int [Accessed 10/09/ 2012].

Yanagisawa K, Muramatsu Y, and Kamada H (1992) Tracer experiments on the transfer of technetium from soil to rice and wheat plants. Radioisotopes. 41, 397-402.

Zohary M (1966) Flora Palaestina. Vol. I, II, III (The Israel Academy of Sciences and Humanities, Jerusalem). 